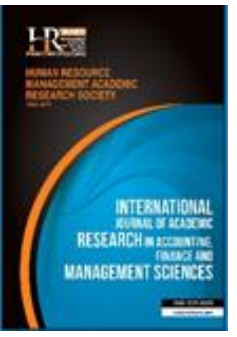

International Journal of Academic Research in Accounting, Finance and Management Sciences

Vol. 10, No.1, January 2020, pp. 71-84

E-ISSN: 2225-8329, P-ISSN: 2308-0337

(c) 2020 HRMARS

www.hrmars.com

To cite this article: Alshoukri, K. O., Karim, A. M., Farhana, N. (2020). The Impact of Leadership on Employee Innovative Work Behaviour in Facilities Management Service Providers in Oman, International Journal of Academic Research in Accounting, Finance and Management Sciences 10 (1): 71-84

\title{
The Impact of Leadership on Employee Innovative Work Behaviour in Facilities Management Service Providers in Oman
}

\author{
Khalfan Obaid Alshoukri ${ }^{1}$, Asif Mahbub Karim², Nadia Farhana ${ }^{3}$ \\ ${ }^{1} \mathrm{PhD}$ Researcher at Binary University of Management And Entrepreneurship, Malaysia \\ ${ }^{2}$ Dean and Associate Professor, Binary Graduate School, Binary University of Management and Entrepreneurship, \\ Malaysia, ${ }^{2}$ E-mail: drasifmkarim@gmail.com (Corresponding author) \\ ${ }^{3}$ Assistant Professor, Department of Business Administration, Stamford University Bangladesh
}

\begin{abstract}
Employee innovative work behavior (EIWB) within organizations plays a key role in achieving the goals of the organization. The current study describes the level of employee innovative work behavior among Facility Management (FM) service providers in Oman and the effect of leadership on employee innovative work behavior before then after an employee motivation has been included as mediator. It focuses on mid-level managers, technicians and supervisors of FM service providers in Oman. Self-structured questionnaire that utilized a set of questions which measure leadership, employees' motivation besides employee innovative work behaviour used as a data collection instrument. Sample size was 320 employees from four FM service providers. The regression analysis identified employees' motivation partially mediates the relationship among leadership and employees innovative work behavior. Additionally, the mean values show that the levels of employee innovative work behavior among employees are moderately high. The outcomes of this paper recommend that leadership, presence an influential-motivation instrument for depicting the innovative work. The current paper offers an insight into workers 'creative change in work behavior arising from leadership and enthusiasm for their career and organization. Besides drawbacks, the paper also addressed the implications.
\end{abstract}

Key words

Leadership, Motivation, Employee Innovative Work Behaviour, Job Security

Received: 10 Feb 2020 (c) The Authors 2020

Revised: 20 Feb 2020 Published by Human Resource Management Academic Research Society (www.hrmars.com)

Accepted: 27 Feb 2020 This article is published under the Creative Commons Attribution (CC BY 4.0) license. Anyone may Published Online: 10 Mar 2020 reproduce, distribute, translate and create derivative works of this article (for both commercial and non-commercial purposes), subject to full attribution to the original publication and authors. The full terms of this license may be seen at: http://creativecommons.org/licences/by/4.0/legalcode

\section{Introduction}

The construction industry in the Sultanate of Oman has observed a growth development various projects have expanded significantly (Molavi, 2018). Some argues that there is a pressing demand for facilities management because of successful growth of the construction industry in the Middle East (Faghih \& Zali, 2018). Moreover, Oman's construction sector continues to grow despite the wake of lower oil prices which cause cuts of public investments. This industry supported through nation-led diversification efforts in addition to noticeably low labour expenses. The construction business grew by 10.4 percent in 2017 (Arezki et al., 2018; Heilbrunn et al., 2019).

The organizational competition with the present business is extremely difficult due to the conations of governmental guidelines modifications as well as the global competition. Thus, the continuation of innovation process is an essential source for organizations as well as economies to be survived. Accordingly, 
firms are progressively should have the interest to examine elements which related to increase the innovative work beheavior (Fatima et al., 2017; Kremer et al., 2019). However, innovation concept has been discussed in the literature but; still, a fairly minor portion of the literature focuses on the FM service providers innovative work behaviour. Also others stated that, firm's values in addition to resources for instance; the factors of innovative work behavior of the employee in the organization (Zenga et al., 2017). It is understood that observes of the ethical FM should be encouraged in addition to be supported. For instance, to increase the requirement for social responsibility between the workforce. The performance of the several service providers is directly affecting the quality of FM services. Various scholars have discussed the accentuating beneficial of quality through engaging real-estate service providers at all levels of an FM association. Consequently, organizations are interested increasingly for the investigative of issues that influence the employees IWB (Fatima et al., 2017; Agarwal, 2014).While the inspiration of different leadership styles on innovative work behavior has been covered earlier, though, there is little among the FM service providers with regard of relationship between leadership and employee IWB in Oman. Also others stated that, organizational executive values besides resources as the determinants of association's EIWB (Zenga et al., 2017).

As leadership is so significant element as the organizational phenomenon and its effects, in shaping behaviours in addition approaches of groups are long lasting and durable. In consequence, leaders play an essential role to shape the organizational work environment over boosting besides assistant the employees to restraint the traditional methods towards their capabilities to generate as well as implement fresh ideas (Bagheri \& Akbari, 2018; Kremer et al., 2019). There is scare of literature around the relationship among leadership besides FM service provider's employee. Though the impact of different procedures of leadership on employee IWB has been covered in past.

\section{Literature review}

\subsection{Facilities Management (FM)}

FM has been all over the places subsequently the invention buildings and facilities. FM departments acknowledged for increasing organization's productivity and cost savings. Therefore, FM plays a strategic role in an organisation. Innovative approaches are often reluctant for investment by property development industry (Dodgson, 2018). Facilities management (FM) activities cover several zones. For example, security, real estate super-vision, financial as well as change management and utilities supplies. FM managers collaborating successfully with other specialists. Also, they are involved at all stage of the innovative behaviour delivery process in order to achieve organization goals. Limited parties that have a comprehensive understanding with the chances as well as contributions provided by facilities management sector. FM would supply the specific requirements of the organisation also is associated with the strategy of the establishment (Curley \& Salmelin, 2018).

There is necessity for FM to be innovative as discussed by many scholars. Preparation for a competitive future is a must for FM service providers. FM should be developed to be further proactive instead of reactive. Therefore, innovative skills are necessary to generate ideas in FM. They should have innovative ability in competitiveness. For example, procedures which add-value for investors and stakeholders and developing new improved facilities (Salaj et al., 2018; Kremer et al., 2019).

\subsection{Oman economic strategy}

Oman is presently succeeding with the governmental strategies in addition to plans to turn its economy from oil-based to a tourism-based economy (Faghih \& Zali, 2018; Al Busaidi et al., 2018). Oman has been a member of World Trade Organization (WTO) since 2000. For Omanis' citizens job insurance, to reduce dependence on expatriates there was a promotion of an "Omanisation" campaign since 2000. A massive repatriation of expatriates who were replaced with Omanis', over 130,000 between January 2015 and July 2018 (Heilbrunn et al., 2019).

The main economic scheme of the Sultanate is one of diversification in order to support the smalland medium-sized enterprises (Faghih \& Zali, 2018). The observed indications are strongly recommends that improvement of the workers' productivity is imperative for a successful economic change. One of the innovation-based competitive rewards of Oman is its graduates in science and engineering. Also Oman has 
been able to carry out the modification of the structure of output, from a few primary products to the manufacturing and export of a variety of overproduces.

The Omanis science and engineering graduates are potentially present two powerful forces for the promotion of future industrial and infrastructure projects in Oman. Therefore, Oman should focus on plans and policies to develop a future innovation-based economy which boosts the chances of flourishing inside the country.

\subsection{Inclusive leadership}

Numerous theories on leadership are focusing on the evaluation in addition to the consideration of leadership method. Leader create change through evaluating the change of environment's that supports employees innovative change and successful together with supporters. The comprehensive initiative even goes further with the thought that social dynamism is the establishment of person's compelling capacities (Wang et al., 2019; Rosile et al., 2018; Alsughayir, 2017).Over and above to have the administrative abilities, a leader should drive initiative and improve in addition to continue with positive functioning relationships in the association (Akram et al., 2016; Alsughayir, 2017). Consequently, leadership not only grounded at the characters of the leader but also there is social procedure which happens among followers as well as the leader, so leadership is an inclusive procedure.

The inclusive leadership attends to three specific helpful behaviours of a leader, including honesty, accessibility, and availability, similar to other leadership styles, for example servant leadership, which is considered thru a leader's specific attitude (Choi et al., 2017; Moon et al., 2018; Janssen, 2005).

Inclusive leadership has been considered as an approach of inclusive leadership presenting leaders' explicit responsiveness of the followers' with their essentials besides his availability . Inclusive leadership is preserved by means of a leadership style parallel to numerous other leadership approaches for instance, the ethical leadership as well as transformational leadership (Choi et al., 2017).

\subsection{Employee innovative work behavior}

Employee innovative work behavior (EIWB) is grounded on an employee activities that are presented by the individuals in addition to their wish is to develop the current environments (Akram et al., 2016; Alsughayir, 2017). EIWB is very important for whole organizational workforce not only significant for the innovation- oriented associations or departments (Hassan et al., 2018). Some concluded that EIWB is considered as a significant strength for organizational goals accomplishment in rapidly changing business world. Due to the enhanced significance of advancement as a vital element for company's achievement notwithstanding endurance, investigation of those elements that develop innovative of employee's attitudes have been furthermore expanded (Widmann \& Mulder, 2018). Researchers have generally defined the employee IWB as the planned initiations in addition to efforts led by individuals/employees to generate new ideas, supporting those ideas as well as implementing ideas (Chen \& Leung, 2016; Bagheri \& Akbari, 2018). Innovative work behavior is consistently considered as the premise of progress in the association alongside advancement in the affiliation.

Regardless of whether affiliations are skilled to build up their presentation by presenting more development has been a significant subject of concentrate by the analysts too as specialists. A few investigations, for example, (Akram et al.,2016; Alsughayir, 2017; Kremer et al., 2019) found inventiveness is an imperative element that a significant supporter of association's long haul achievement and endurance just as encouraging associations to have a practical upper hand over contenders.

\subsection{Inclusive leadership and employee innovative work behavior}

The inclusive leadership is an inter-personal interactions relation and is defined as a configuration of mutual interfaces among leaders besides followers. Moreover, it is sympathetic as well as intensive on developing exertion and relationships inside the business (Ye et al., 2019; Moon et al., 2018; Janssen, 2005).

The idea generation from an individual is first stage of innovation. Overall honesty, accessibility as well as the accessibility facilitated employee engrossment in innovative work (Widmann \& Mulder, 2018; Ye et al., 2019; Kremer et al., 2019). Innovation is nominal for increasing the quality of performance as it 
improves the effectiveness of facilities delivered by staffs thru improving the probability and essence of new idea generating attitude realization (Fatima et al., 2017 ), Argued that supporters of a participative leader are supplementary expected to demonstrate citizenship behavior through good performance. Then consequently improving the competitiveness and organizations success through the implementation of those ideas (Ye, et al., 2019). At present, attaining innovativeness for organizations sectors is an essential goal. There is an essential requirement to recognize the leadership in addition to the effect of organizational environment on innovative work behavior in associations (Bagheri \& Akbari, 2018). Success in new product development is not independent of the firms operation environment (Ye et al., 2019).

Inclusive leadership's special features reshaped adherents' attention to help and upgraded increasingly creative work behaviour. Perceived work-related difficulties, incongruities, disagree-ties, and emerging trends are of the leaders of the generation of fresh ideas. Consequently, from the organizational support theory, the author formulated the first hypothesis of this paper:

$H_{1}$ : Inclusive leadership is positively related to employee innovative work behavior.

\subsection{Job Security (JS)}

JS was based in the organizational support theory, highlighting the significance of observing employees as valued organizational resources (Halder \& Argyropoulos, 2019). Leader might deliver benefits that dependents can create use of. Linking leadership to employee's innovative work behavior remains under-developed. In this segment, the mediating role of Job Security will be situated and explained. In what way leadership affects Job Security will be presented. Then consequently the influence of Job Security on employee innovative work behavior will be described. Superiors in leadership roles play an important role through provision of organizational resources as well as rewards for dependents. Therefore, would be considered as an important cause of organizational support. Organizational support theory expressed that, employee's perception of favourable conduct established from the association, for instance supportive attitude from supervisor would increase JS (Halder \& Argyropoulos, 2019). Sympathetic behaviors from leader assisted dependents perceive that their offerings were valued and their happiness were being concerned around as well as must enhanced JS (Halder \& Argyropoulos, 2019).

As a result, supportive attitude from leaders would be positively related to JS. The authors suggested hypotheses subsequently as follows:

$\mathrm{H}_{2}$ : Inclusive leadership is positively related to Job Security.

Innovation and impulsive problem solving might furthermore be related with perceived superiors backing. Job Security is the employ feeling without fear of negative consequences to self-image (Basharat et al., 2019; Tobias \& Jochen, 2019). In a dependable work place atmosphere, individuals have a habit of feeling safe at work. Employee's innovative work behavior can be encouraged through the encouragement a work situation in which employee's intellect supported to generate, encourage as well as realize inventive ideas in addition to concepts. Leaders and supervisors in the workplace are expected to play an immense role in shaping Job security. Essential, on the establishment of social exchange theory, Job security ought to inspire the standard of correspondence, prompting worker's commitment to assist the relationship with accomplishing its targets, just as the desire that expanded endeavours for the association's benefit would be seen and compensated. In compare, if individuals cannot trust other organization members, one will perceive the workplace to be ambiguous, unpredictable and threatening (LI \& Jin, 2009; Sabbir et al., 2018). On the other hand, once workforces feel low support of association, their immersion in improvement would be conical. Thus, the trustworthiness largely shapes the safe perception of workplace environment (Basharat et al., 2019; Matti \& Kristi, 2018). The cognitive trust is constructed on knowledge about the trustee besides the interaction history. In the same way, workers who sensed more job security experience an enhanced needs-supplies suitable in addition increased creativity. Other asserted that organizational care, which was positively related to JS, positively presume employee innovative work attitude. Therefore, the authors suggest the following hypothesis:

$H_{3}$ : Job security is positively related to employee innovative work behavior.

As stated by social exchange theory, the extra desired inclusion, authorisation as well as resources personnel received from the leader and the association. Leadership might affect employee innovative work behavior over the job security. The greater the job security in addition to the more motivated and being 
added involved in employee innovative work behaviors. For the assistance of the individuals in unleashing their innovation prospective, employees could need an over-all sense that leaders presented support. Workers were exceptionally sensitive to pioneers' conduct and activities for data on what was normal and satisfactory in hierarchical association. Besides, initiative can encourage a feeling of responsibility in the affiliation. On the off chance that a pioneer was and welcomed difficulties, workers were probably going to see increasingly calculated help notwithstanding turned out to be more innovative. Intended for saw provision in spot of advancement is a significant reason for development generally inventiveness. From one viewpoint, if pioneers care about dependents' requirements also sentiments, gave positive reaction, support representatives to incite their own thoughts besides improve their capacities, and helped them take care of occupation related issues, executive faithfulness as well as Employees ' enthusiasm for work will significantly develop, expanding their energy to find and improve. The employee's confidence will increase significantly and they will demonstrate more voluntary acts, additional increasing their capabilities in addition consciousness of innovation.

Leaders may championing innovation and invigorated to discover employee innovative methodologies in their exertion. With regard to above, job security increased the prospect that employees be develops extra creative solutions in addition to styles of addressing problems. Leadership delivered to teams the exclusive awareness of supportive acts from leaders that would increase employee innovative work attitudes. Leadership can affect employee IWB through the inspiration on workers' acuities of an environment sympathetic of innovation. Therefore, the author projected the fourth hypothesis:

$\mathrm{H}_{4}$ : Job security mediates the relationship between leadership, employee innovative work behavior.

The hypothesis model of the current study is illustrated in Fig 1.

\section{The framework and hypotheses}

Following hypotheses were produced for current paper, with regard to issues discussed above in the review of literature. Relationships between inclusive leadership, employee innovative behaviour and job security shown in conceptual framework in Figure 1.

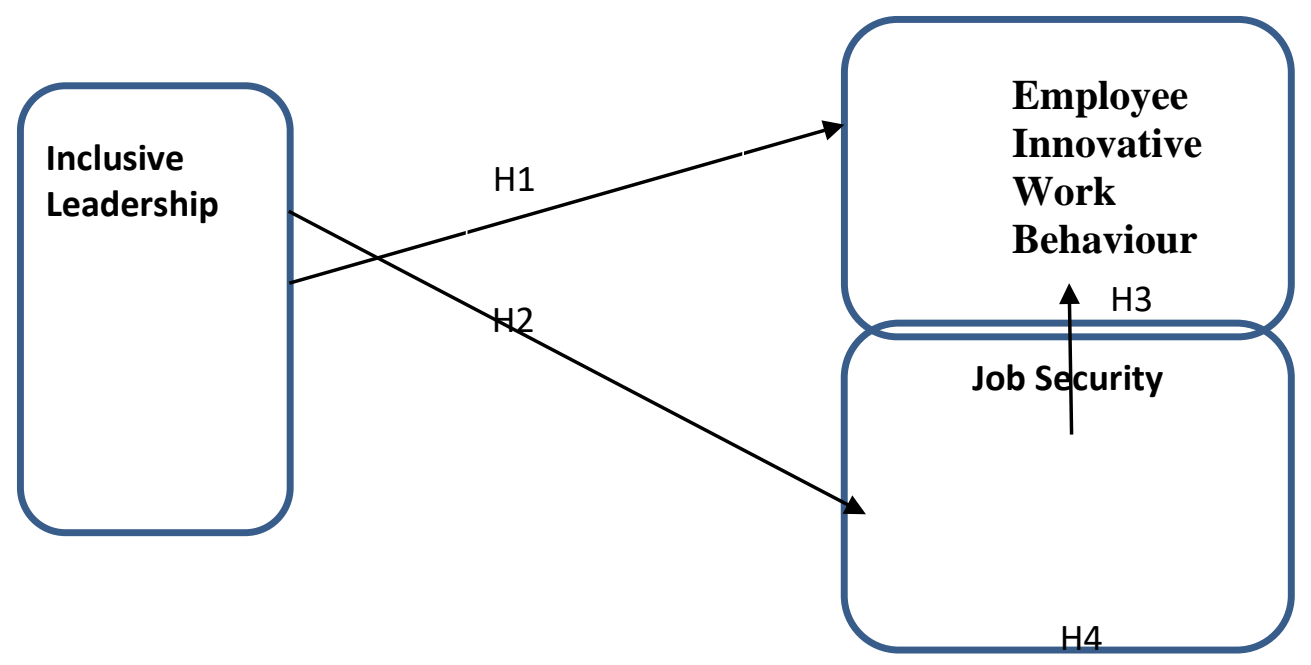

Figure 1. Conceptual framework

\section{Hypotheses}

This study is guided by the following four hypotheses:

H1. Inclusive leadership is positively related to employee innovative work behavior.

H2. Inclusive leadership is positively related to job Security.

H3. Job security is positively related to employee innovative work behavior.

H4. Job security mediates the relationship among leadership and employee innovative work behavior 


\section{Methodology of research}

\subsection{Sample}

Sultanate of Oman is an Arab country on the south eastern coast of the Arabian Peninsula in Western Asia. Population is over 4 million (2.23 million Omani, 1.76 million expatriates). Categorized as a highincome economy according to the Global Peace Index, a significant portion of its economy involves Oil, gas, tourism and agricultural products.

Oman National Engineering \& Investment Co. was formed in 1978. Subsequently commencement, the company backed by committed shareholders, as it has registered stable rowing progress progressive management. The enthusiastic professional workforce about 5000 Oman International Group Company has developed interested in Facilities Management Company in Oman. OIG Company was established in 1976. They are providing vital support services. There operations also include environmental health and design \& installation of landscaping and irrigation systems. OIG assigned dedicated professional staff around 5000.

Genetco is regarded as the leading Facility Management provider in the Sultanate of Oman. Over the past four decades they have earned an outstanding reputation with operations across the Sultanate. Genesco's Facilities Management Division currently employs a team of around 5000 staff with a wealth of experience and expertise to meet customers' requirements. Oman Shaporjee Co 1975 Have 6000 employees. Facilities Management Division currently employs a team of 5000 staff.

\subsection{Sampling method and technique}

For the data collection process and due certain limitations, the author in this paper used nonprobability convenience sampling technique. The researchers employed questionnaires containing items related to leadership; employees' motivation and innovative work behavior were included. The scale was referred; the stages of ideas generation, promotion and the implementation with reliability values of 0.89 , 0.93 and 0.90 respectively. In this paper, leadership was the independent variable, while employees' motivation was a mediator and employee innovative work behavior was dependent variables. All items on the questionnaire were measured by using a 5 -point Likert scale with a value of $1=$ 'strongly disagree' to 5 $=$ 'strongly agree'.

The questionnaire of leadership was established as well as certified by (Carifio, 2010). Likert scale (5 point) was utilized to measure the relationship among leadership besides employees' IWB. As subscales identified leadership including idealized influence behavior, inspirational motivation, intellectual stimulation and individualized consideration. The coefficients were $0.90,0.89,0.91$, and 0.80 , respectively.

These dimensions are inclusive, empowering and ethical. Individual element has 5 items by a.90 reported $\alpha$ for measures totally. With the intention of the employee IWB measurement, the author utilized scale established by (Janssen, 2000). It has magnitudes specifically by value of $\alpha=.94$ (Janssen, 2000). The dimensions cover idea generation, promotion as well as the implementation of those ideas.

\subsection{Data collection procedure}

The author utilized a self-administered data collection technique. All ethical factors had been taken under consideration. The respondents were invited to read in addition to understand then to fill up the questionnaire. Some demographic information from respondents was also collected. Additionally, the author claimed that aim and objectives of the current paper are purely for academic.

\subsection{Measures}

Toward getting the best out of the validity and reliability of the dimension tools, the author utilized current scales issued in highly ranked published papers. The author was conducted a pilot study to assure the appositeness study design and expression. The questionnaire turned into then revised primarily based on comments concerning the pre-survey. The author utilized a five-point Likert was utilized by the author; scale ranging from 1 to 5 . 


\section{Leadership:}

The author assessed leadership by make use of a five-item measures that were established by Carmeli et al. (2010). A sample item was: "The manager is open to hearing new ideas." The coefficient $(\alpha)=$ 0.927 ; showing that the reliability was satisfactory.

Job Security (JS):

The author utilized Preacher software within SPSS to test the mediation effect of job security on the relationship among leadership and innovative work behavior. An example element was: "My organization takes pride in my accomplishments at work" (Preacher \& Hayes, 2004). The reliability $(\alpha)=0.952$; showing a well satisfied reliability factor.

Employee innovative work behavior (EIWB):

The author measured employee IWB a five-item established by Janssen (2000). The $(\alpha)$ reliability = 0.951; showing that paper has a good reliability measure. It measured three features of "the generation of the idea" also "idea promotion" as well as "the implementation of new created ideas"

Control variables:

With regard to the earlier discussed literature, the author selected gender, age, FM service providers in Oman, and staff occupation in organization by means of main control variables for their possible in firm's roles and objectives in order to identify the organizational funding besides the employee innovative work behavior.

\subsection{Hypotheses testing approach}

The author followed Hayes' methodology for the analysis the assumptions main effects as well as the mediation effect. The author utilized Preacher software within SPSS (Preacher \& Hayes, 2004).ANOVA, Hayes' bootstrapping method is considered robust against measured parameters Mediation models were tested including $95 \%$ bootstrap confidence intervals.

\subsection{The analysis and results}

347 were the over-all questionnaires that dispersed between four facilities management service provider's staff at different management level. 320workerswere fully replied to the survey and 4 questionnaires were not filled up. However, 19 questionnaires were partially filled. Therefore, the author had excluded those 23 questionnaires from analysis of the current paper.

The author utilized IBM SPSS program. Some demographic data was furthermore composed from the respondents in order to realize the respondent's features specifically manage engineers and supervisors. Correlation and linear regression assessments were applied by the author. The ages of contributed respondents were between 20 years to or above 46 years. The section subsequently showing of current studies results.

\subsection{Descriptive statistics a}

Descriptive statistics were reported in table 1 below. It indicates that the mean values of idea generation, promotion as well as the idea implementation are $7.5238,7.3333$ and 12.0000 respectively. While, leadership has mean of 8.4352 as well as 11.3095 is the value of total EIWB.

Table 1. Descriptive statistics ( $\mathrm{N}=320)$

\begin{tabular}{lccccc}
\hline \multicolumn{1}{c}{ Variables } & Minimum & Maximum & Mean & Std. deviation & Level* \\
\hline Idea Generation & 6.00 & 12.00 & 7.5238 & 1.85101 & moderate \\
Idea Promotion & 5.00 & 10.00 & 7.3333 & 1.60284 & moderate \\
Idea Implementation & 8.00 & 15.00 & 12.0000 & 1.59267 & moderate \\
Leadership & 5 & 10 & 8.4352 & 1.03561 & moderate \\
EIWB & 6.00 & 19.00 & 11.3095 & 1.81442 & moderate \\
\hline
\end{tabular}

${ }^{*}$ As scored by (Ismail \& Mydin , 2018) 
Table 2. Means, standard deviations, and correlations among main variables $(n=320)$

\begin{tabular}{|c|c|c|c|c|c|c|c|c|c|}
\hline Variable & Mean & SD & 1 & 2 & 3 & 4 & 5 & 6 & 7 \\
\hline 1. Gender & 0.438 & 0.572 & 1 & & & & & & \\
\hline 2. Age & 2.518 & 0.605 & $-0.234 * *$ & 1 & & & & & \\
\hline 3. Education & 1.783 & 0.575 & $-0.210 * *$ & -0.034 & 1 & & & & \\
\hline 4. Tenure & 3.084 & 1.239 & 0.029 & $0.368 * *$ & -0.105 & 1 & & & \\
\hline 5. leadership & 4.441 & 0.600 & $0.154^{*}$ & -0.002 & -0.047 & 0.076 & 1 & & \\
\hline 6. JS & 4.365 & 0.730 & 0.112 & 0.070 & -0.046 & 0.102 & $0.697 * *$ & 1 & \\
\hline $\begin{array}{l}\text { 7. Employee innovative } \\
\text { work behavior }\end{array}$ & 3.860 & 0.806 & 0.238 & $0.182 * *$ & $-0.173 * *$ & $0.264 * *$ & $0.302 * *$ & $0.279 * *$ & 1 \\
\hline
\end{tabular}

Note: $(n=320), * * p<0.01, * p<0.05$ (two-tailed)

\subsection{Descriptive statistics $b$}

The correlations among variables and the descriptive statistics were shown in table 2above. According to the aim as well as assumptions of the current paper, table 1 showing that, $(r=0.302 ; p<0.01)$ this means leadership is positively correlated with employee IWB. In addition, JS $(r=0.697 ; p<0.01)$, and JS is positively related to Employee innovative work behavior $(r=0.279 ; p<0.01)$.

\subsection{Correlation analysis}

A bivariate correlation exploration was carried for the purpose of finding out the relationship path in addition to strength among leadership and the employee IWB stages. Correlations among variables that have mediating role of motivation on the relationship among inclusive leadership with employee innovative work behavior were shown in table 3 . The style of leadership (inclusive) is absolutely and significantly correlates through the idea generation, promotion and the implementation as well as the total EIWB.

Table 3. Correlation among variables mediating role of motivation on the relationship among leadership with employee innovative work behavior

\begin{tabular}{lcccccc}
\hline \multicolumn{1}{c}{ Variable } & Charisma & $\begin{array}{c}\text { Inspirational } \\
\text { motivation }\end{array}$ & $\begin{array}{c}\text { Work } \\
\text { engagement }\end{array}$ & $\begin{array}{c}\text { Intellectual } \\
\text { stimulation }\end{array}$ & $\begin{array}{c}\text { Motivation } \\
\text { Employee } \\
\text { innovative work } \\
\text { behavior }\end{array}$ \\
\hline Charisma & 1 & $.833^{* *}$ & $.855^{* *}$ & $.789^{* *}$ & $.406^{* *}$ & $.465^{* *}$ \\
$\begin{array}{l}\text { Inspirational } \\
\text { motivation }\end{array}$ & $.833^{* *}$ & 1 & $.918^{* *}$ & $.857^{* *}$ & $.406^{* *}$ & $.527^{* *}$ \\
$\begin{array}{l}\text { Work engagement } \\
\text { Intellectual }\end{array}$ & $.855^{* *}$ & $.918^{* *}$ & 1 & .876 & $.441^{* *}$ & $.563^{* *}$ \\
$\begin{array}{l}\text { stimulation } \\
\begin{array}{l}\text { Motivation } \\
\text { Employee innovative } \\
\text { work behavior }\end{array}\end{array}$ & $.798^{* *}$ & $.857^{* *}$ & $.876^{* *}$ & 1 & $.407^{* *}$ & $.502^{* *}$ \\
\hline
\end{tabular}

Note: ${ }^{* *}$ Correlation is significant at the 0.01 level (2-tailed)

To measure the relationship among leadership in addition to its dimensions, motivation as well as employee innovative work behavior, the author computed a Pearson product-moment correlation measurement. Correlation among leadership, motivation and employee innovative work behavior results were shown in table 3.There is a positive significant correlation among the three main variables. In general, the results indicate that transformational leaders are able to increase the employee's motivation and employee innovative work behavior. 
Table 4. Unstandardized coefficients of the model

\begin{tabular}{lllccc}
\hline \multicolumn{1}{c}{ Effects } & Hypothesis & Estimate & SE & $\begin{array}{c}\text { 95\% } \\
\text { confidence } \\
\text { intervals }\end{array}$ \\
\hline Direct effect & Inclusive leadership $\longrightarrow$ mployee innovative work behaviour & $.356^{* *}$ & .081 & {$[.183,0.467]$} \\
& Inclusive leadership $\longrightarrow$ Job Security & $.876^{* *}$ & .07247 & {$[.624,0.977]$} \\
& Job Security $\longrightarrow$ moloyee innovative work behavior & $.253^{* *}$ & .069 & {$[.112,0.421]$} \\
\hline $\begin{array}{l}\text { Indirect } \\
\text { effect }\end{array}$ & $\begin{array}{l}\text { leadership } \longrightarrow \text { Job Security } \rightarrow \text { Employee innovative work } \\
\text { behaviour }\end{array}$ & $.206^{* *}$ & .0724 & {$[.096,0.327]$} \\
\hline
\end{tabular}

\subsection{The level of employee's innovative work behavior results}

The first objective of this paper is to identify the level of employee innovative work behavior among respondents. Table 1 shows the mean value where the level of employee innovative work behavior of respondents is moderate $(M=11.3095$ and $S D=1.81442)$. Amongst employee IWB measurements, the segment of the idea generation shows the highest level, followed by stage of promotion. Nevertheless, all the dimensions are at highly moderate level as scored by (Ismail \& Mydin, 2018).

The author utilized Preacher software within SPSS to test the mediation the consequence of job security on the relationship among leadership besides the innovative work behaviour (Preacher \& Hayes, 2004). ANOVA, Hayes' bootstrapping method is considered robust against measured parameters mediation models were tested including $95 \%$ bootstrap confidence intervals. Also, the linear regression test was conducted by the author. The inclusive leadership and motivation were considered as predictor variables while the outcome variable; employee's innovative work behavior is examined.

The R2 value in Model 1 indicates that the change of variance in the employees innovative work behavior explained by the leadership is $0.30 \%(\beta=0.54 ; p=.01)$. Whereas, Model 2 , the $R^{2}$ indicates that $35 \%$ $(\beta=0.43, p=0.01$ ) of the variance changes in the employees employee innovative work behavior can be explained by leadership and employees motivation. The significant of three paths (direct and indirect effect) and the decrement of the $\beta$ value of leadership after the inclusion of mediator (employee's motivation) in Model 2 dictates that motivation is a significant partial mediator.

The author utilized Preacher software within SPSS to test the mediation effect of job security on the relationship among leadership and innovative work behaviour (Preacher \& Hayes, 2004). ANOVA, Hayes' bootstrapping method is considered robust against measured parameters mediation models were tested including $95 \%$ bootstrap confidence intervals. Table 4 presents the model unstandardized coefficient estimates.

Table 4 showing the results, subsequently by controlling factors of the education, tenure, age as well as gender the unstandardized coefficients of the model. From table 4 , the coefficient beta $=.356^{* *}$, the standard error equals $0.081, p<0.01$, with the confidence of $95 \%$ Leadership was positively related to EIWB. Because the $\mathrm{Cl}=[0.183,0.467])$ and a zero was not comprised in this number. Hypothesis 1 was supported, as discussed above. This demonstrating that if an individual perceived higher inclusive governance, they revealed more employees IWB.

There was a positive relationship among job security and the inclusive leadership; JS $\left(\beta=.876^{* *}\right.$, SE $=$ $0.07247, \mathrm{p}<0.01$, with the 95percent confidence. Hypothesis 2 was supported as the value of $\mathrm{Cl}=[.624$, 0.977]). This outcome showing that individuals experienced more job security once they professed or get more inclusive leadership. Job security was positively related to employee IWB (the beta coefficient = $.253^{* *}, \mathrm{SE}=0.07247, \mathrm{p}<0.01$, with percent of 95 confidence. Hypothesis 3 was supported as the, $\mathrm{Cl}$ value is $[0.112,0.421])$. This result demonstrated that when employees perceived more organizational support, they inveterate more innovative behavior. The inclusive leadership was positively related to EIWB through job security $\left(\beta=0.206^{* *}, \mathrm{SE}=0.0724, \mathrm{p}<0.01,95 \% \mathrm{Cl}=[0.096,0.327]\right)$. Moreover the findings shows job security mediated the relationship among the EIWB as well as the inclusive leadership.

\section{Discussions}

The objective of the current paper was indented to explore the general consequence of the inclusive style of leadership on employee IWB in FM service providers in Oman. It is suggested that FM service 
providers in Oman have their effort in becoming employee innovative in doing their job tasks. These results can be utilized to inculcate innovation and invention as a culture in FM service providers in Oman system as employee innovative individual able to generate new ideas and translate the curriculum goals and needs by using creative and employee innovative methods It also First, it was hypothesized that there is a positive relationship among the inclusive leadership and the total EIWB. H1 was not rejected. It was supported as the scheme were showing positive correlations as well as positive regression of the effect of the inclusive style of leadership on segments of the EIWB of FM service providers in Oman. The author secondly hypothesized in the current paper that there was a positive relationship among the inclusive leadership is and the job Security of FM service providers in Oman. The outcomes similarly reinforced this assumption as well as showed a positive correlation in addition to substantial regression consequences of FM service providers in Oman. Therefore, fail to reject H2. Hypothesis 3 shows that there was a positive relationship among the job security and the employee innovative work behavior in employees of FM service providers in Oman. Result showed an important positive correlation in addition to regression for the effect of leadership and of FM service providers in Oman.H3 is also supported and not rejected. As innovation behavior becoming a crucial aspect in developing and sustaining an organization performance, the author in the current paper was attempted to investigate the role of transformational leadership in promoting this aspect among FM service providers in Oman. The results have revealed that employee innovative work behavior of FM service providers in Oman are indicated moderate. $\mathrm{H} 4$ claimed that job security mediates the relationship among leadership as well as the innovative work behavior of FM service providers in Oman employees. Outcomes were ensured a significant correlation as well as positive regression value, for that reason, $\mathrm{H} 4$ was not rejected. Accordingly, FM service providers in Oman need to heighten its effort with the aim of increase the level of employee IWB among FM service providers in Oman. Leadership is one of the important aspects that contribute to the employees' innovative work behavior. The current paper results showed the significant direct consequences of leadership on employees employee innovativeness and this results are consistent with previous findings such study (Brimhall, 2019; Tobias \& Jochen, 2019). They were stated that once an individual or else worker recognize that his superiors and leaders are sympathetic; their participation would be enhanced innovatively through stages of EIWB. The organization would achieve the objectives the generated ideas will reach to the implementation stage (Brimhall, 2019; Janssen, 2005). The current paper stated that, FM service provider's employees in Oman being offered by their superiors/ leaders inclusively in addition to representing motivational to work innovatively. This supported and strengthens the statement of this paper. Further, this study also as finds that motivation has a significant mediating role scheduled the connexion among leadership with employee innovative work behavior. This finding suggests that the influence of leadership on employee IWB is going to increase if individual are committed to their organization and their work. As explained by (Zenga et al., 2017; Tobias \& Jochen, 2019), the process of fostering Employee innovative work behavior in an organization does not solely lie on effective leadership, but it also depends on employees ' motivation.

In summary, it is suggested that the leadership and the motivation can bring about the improvement of employees employee innovative work behavior. FM leaders, who are better address all the challenges and consider employees motivation as important aspect in promoting innovation among individuals, will improve the work performance.

\section{Conclusions}

Organizational abilities are not adequate to employ such an imperative source alone rather leaders correspondingly essential to exist in a situation that would take inventiveness then nurture as well as preserve a optimistic well-designed relationship through supporters (Watt, 2013). The author incurrent paper aimed was to explore and to investigate whether the leadership has or not an optimistic influence to the employees' IWB of FM service providers in Oman. In continuation, based on social exchange theory and organizational support theory it meant to investigate in what manner powerfully leadership possessions the employee IWB in FM service providers in Oman. The hypotheses were supported by the outcomes of the current paper. For that reason, leadership has remained bring into being as an essential tool for snowballing the innovative capability of logistic workers. Specifically, once employees and individuals observed that leaders exhibited with an extra awareness as happiness to their fresh ideas, skills as well as 
procedures, they perceived animation take an interest about the association, accordingly, improved their employee IWB. Steady by means of organizational support theory, the author established that leadership was absolutely related to EIWB along with job security mediated the relationship among leadership as well as EIWB.

Nevertheless, to guarantee developed competitive advantages the circumstances demands special care economy in current marketplace concerned. By means of, using resources in an appropriate as well as useful way. The author concluded that leadership has the effect to improve and enhance the innovative of organizational individuals as well as the employees. Furthermore, the author in current paper assisted in sympathetic the countryside of this relationship among leadership as well as stages of EIWB till the implementation of created ideas.

Future studies in FM service providers in Oman should inspire FM industries at the side of utilization of the internet facilities as information technology is expanded dramatically. To sum up, this study was conducted by using of FM service providers employees in Oman sample, nevertheless, further studies could be conducted on GCC countries.

\section{Practical and theoretical Contributions}

\subsection{Practical contributions}

For instance organizational competiveness depends on the employee IWB. There were an essential requirement identify by what means FM service providers leaders in Oman can encourage their individuals and supporter innovation. Outcomes of the current paper propose a number of suggestions for Omani FM service Providers leaders. It made a numerous contributions for improvement of the Omani employees IWB. Facilities management service providers' organizations have to have the necessity assurance of promoting leadership among their leaders. This paper set the theoretical model as FM managers can develop firm's employee IWB in a positive manner. Leaders must have initiative criteria and be more inclusive, ethical approaches and behave. Firm's administrative staff and supervisors should be with clear vision of the organization. Those only could be capable of growth and enhance the innovative work behavior among their individuals or followers.

The author proposed and suggested that training programs about leadership among superiors possibly will help leaders to motivate the idea generation behaviour. In addition leaders will realize the importance of kindness the improvement of different skills in order to support the employees for the promotion of their developed ideas.

As it was indicated by the results that leadership obligated with an important effect on FM service providers in Oman employee IWB. In continuation, the exploration of the literature supported the importance of managerial support in employee innovative work behavior. Therefore, managers should build up skills to persuade workforces engage in employee innovative work behavior.

Leadership style is a proper tool to entertainment as an innovation-facilitating strength by increasing job security. As well as hrough the encouraging individual and employees in FM organization intellectually to improve existing techniques and process. Current paper is one of few studies that investigated the power of leadership on job security as well as employee innovative work behavior in Oman. This literature gap as well as practical consensus weighed down the helpfulness of leadership in FM service providers.

Other researchers stated with progressive leadership works by complementing the classic social exchange theory as well as support theory framework. Furthermore, these theories taken in to interpretation for support-based the difference of consequences that focus on employees' job security. As stated in the literature, inspiration of the innovation can be enhanced through the organization especially if the employees have the ability to change. Additionally, the employees should act differently and leaders to stand with supporters as well as accept the eccentricity from old and conventional practices. While the concept of leadership has received cumulative consideration in modern administrations, leadership remained a new idea with no compromise on the environment of the concept otherwise the situation theoretical ground works. In addition, the results of the current paper were highlighted the role of job security as a mediator among in FM leadership service providers and FM employees IWB in Oman. Earlier investigations had not investigated the Omani FM service provider's mechanism that relates among FM service providers leadership as well as FM IWB of FM organizational employees in Oman. The author in the 
current paper stated that, findings had contributed to the literature. The outcomes presents that FM leaders of service providers in Oman showed that job security is mediating and directly affecting the FM employees IWB.

For the success of competitiveness and long-term success as discussed there were critical issues which have to be addressed by organizations. Although a leadership styles supports idiosyncratic attributions and perceptions of organization's employees. This result asserts that leadership as a driver of Employee innovative work behavior. The results of the current paper support the optimistic impact of the style of leadership on employee IWB which was suggested, this shows the importance of this as well as role in addressing innovation elements. With regard of highly achievement requirement of innovativeness as well as workers' productivity, there is an essential of relations between leaders and their supports.

\subsection{Theoretical Contribution}

This study provides a comprehensive literature review on inclusive leadership, innovative work behaviour in FM service providers since there is a lacking. Thus, the current paper was had investigated the influence of leadership on job security as well as EIWB for FM service providers in Oman. The author in the current paper identified factors that possibly will support employees to skip the difficulties in order to have idea generation environment, then enhance the innovative work behavior. In order to create a superior operational environment training programs are mostly recommended by the author. Consequently, organizational leaders would represent and depict better behavior with their followers.

\section{Limitations of the research}

Several limitations of current paper should be mentioned. Firstly, one should be caution when generalization the conclusion as the sample size was small and not most of FM service providers were covered on communicated this may reduce the generalization. Further investigation might be carried out advance diverse industries by means of expanding the spices as well as sample size. In addition, there are many other mechanisms which influence and exist relationship among leadership and EIWB rather than what have been discussed in the current paper.

\section{Acknowledgement}

The authors would acknowledge the guidance of Global Academics Research Academy (GARA) for publication and assistance of Onism Consultancy for editing and proofreading of the manuscript.

Conflicts of interest

The author declared that this paper only conducted for academic resolves. The assumptions are exclusively prepared on the ground of the composed data. This paper has no role of at all association or else sponsor in the study process as well as interpretation of the data.

\section{References}

1. Agarwal, A. U. (2014). Linking justice, trust and innovative work behaviour to work engagement. Journal of Personnel Review, 43(1), pp. 41-73.

2. Akram, T., Leia, S., \& Haidera, M. J. (2016). The impact of relational leadership on employee innovative work behavior in IT industry of China. Arab Economic and Busines Journal, 08 June, p. 09.

3. Al Busaidi, M., Bose, S., Claereboudt, M., \& Tiwari, M. (2018). Sea turtles tourism in Oman: Current status and future prospects. Tourism and hospitality research, 1-16.

4. Alsughayir, A. (2017). The Effect of Leader-Member Exchange on Innovative Work Behavior in the Saudi Hospitality. International Journal of Business and Management, 12(6), 189 - 195.

5. Bagheri, A., \& Akbari, M. (2018). The Impact of Entrepreneurial Leadership on Nurses' Innovation Behavior. Journal of Nursing Scholarship, 50(1), 28-35.

6. Brimhall, K. C. (2019). Inclusion Is Important ... But How Do I Include? Examining the Effects of Leader Engagement on Inclusion, Innovation, Job Satisfaction, and Perceived Quality of Care in a Diverse Nonprofit Health Care Organization. Nonprofit and Voluntary Sector Quarterly. 
7. Carifio, J. (2010). Development and Validation of a Measure of Relational Leadership: Implications for Leadership Theory and Policies. Current Research in Psychology, 1(1), 16-28.

8. Chen, L. T., \& Leung, K. (2016). When does supervisor support encourage innovative behavior? Opposite moderating effects of general self-efficacy and internal locus of control. Personnel Psychology, Volume 69, pp. 123-158.

9. Choi, S. B., Tran, T. H., \& Kang, S. W. (2017). Inclusive Leadership and Employee Well-Being: The Mediating Role of Person-Job Fit. J Happiness Stud, Volume 18, 1877-1901.

10. Curley, M., \& Salmelin, B. (2018). Open Innovation 2.0 The New Mode of Digital Innovation for Prosperity and Sustainability. 2 ed. Switzerland: Springer International Publishing.

11. Darwish, S., Ahmed, U., \& Pahi, M. H. (2020). Innovative Work Behavior During COVID-19 for Medical Representative in the Pharmaceutical Industry: Test of a Moderation Model in Bahrain. International Journal of Pharmaceutical Research. 12(4), 1927-

1934. doi.org/10.31838/ijpr/2020.12.04.277

12. Dodgson, M. (2018). Technological Collaboration in Industry, Strategy, policy and internationalization in innovation. 1 ed. New York: Routledge.

13. Faghih, N., \& Zali , M. R. eds., (2018). Entrepreneurship Ecosystem in the Middle East and North Africa (MENA). In: Dynamics in Trends, Policy and Business Environment. Switzerland: Springer International Publishing AG, p. 707.

14. Fatima, T., Majeed, M., \& Saeed, I. (2017). Does Participative Leadership Promote Innovative Work Behavior: The Moderated Mediation Model. Business \& Economic Review, 9 (4), 139-156.

15. Halder, S., \& Argyropoulos, V. (2019). Inclusion, Equity and Access for Individuals with Disabilities Insights from Educators across World. 1 ed. Singapore: Springer Nature Singapore Pte Ltd.

16. Heilbrunn, S., Freiling, J., \& Harima, A. (2019). Refugee Entrepreneurship A Case-based Topography. 1 ed. Switzerland: Springer Nature Switzerland AG.

17. Ismail, A., \& Mydin, A. A. (2018). The Impact of Transformational Leadership and Commitment on Teachers' Innovative Behaviour. Malaysia, Atlatis Press.

18. Janssen, O. (2000). Job demands, perceptions of effort-reward fairness and innovative work behaviour. Journal of Occupational and Organizational Psychology, Volume 73, 287-302.

19. Janssen, O. (2005). The joint impact of perceived influence and supervisor supportiveness on employee innovative behaviour. Journal of Occupational and Organizational Psychology, 78, 573-579.

20. Kremer, H., Villamor, I., \& Aguinis, H. (2019). Innovation leadership: Best-practice recommendations for promoting employee creativity, voice, and knowledge sharing. Business Horizons, 62(1), 65-74.

21. LI, N., \& Jin, Y. (2009). The effects of trust climate on individual performance. Frontiers of Business Research in China, 3(1), 27-49.

22. Matti, M., \& Kristi, K. (2018). Bullying and an unfavourable working environment. International Journal of Workplace Health Management, 11(3), 159-176.

23. Molavi, A. (2018). The Real 'New Middle East'. [Online] Available at: http://www.washingtonpost.com/wpdyn/content/article/2006/08/18/AR2006081801027.html [Accessed 2612 2018].

24. Moon, Y. J., Choib, M., \& Armstrongc, D. J. (2018). The impact of relational leadership and social alignment on information security system effectiveness in Korean governmental organizations. International Journal of Information Management, 40, 54-66.

25. Mumford, M. D. (2003). Where Have We Been, Where Are We Going? Taking Stock in Creativity Research. Creativity Research Journal, 15 (2 and 3), 107-120.

26. Preacher, K. J., \& Hayes, A. F. (2004). SPSS and SAS procedures for estimating indirect effects in simple mediation models. Behavior Research Methods, Instruments, \& Computers, 36(4), 717-731.

27. Rosile, G. A., Boje, D. M., \& Claw, C. M. (2018). Leadership was defined differently according to the individuals view like post heroic, distributed, shared, constructed and also relational. Leadership, 14(3), 307-328. 
28. Sabbir, R. M., Mat, D. N., \& Murali, R. (2018). Knowledge sharing behaviour among nonacademic staff in higher learning institutes: The role of trust and perceived risk. Knowledge Management \& E-Learning-An International Journal, 10(1), 113-124.

29. Tobias, M., \& Jochen, W. (2019). Physiolytics at the workplace: Affordances and constraints of wearables use from an employee's perspective. Information Systems Journal, 29(1), 245-273.

30. Wang, Y. X., Yang, Y. J., Wang, Y., \& Su, D. (2019). The Mediating Role of Inclusive Leadership: Work Engagement and School of Nursing, Anhui Medical University.

31. Widmann, A., \& Mulder, R. H. (2018). Team learning behaviours and innovative work behaviour in work teams. European Journal of Innovation Management, 21(3), 501-520.

32. Ye, Q., Wang, D., \& Guo, W. (2019). Inclusive leadership and team innovation: The role of team voice and performance pressure. European Management Journal.

33. Zenga, J., Zhangb, W., Matsuic, Y., \& Zhaod, X. (2017). The impact of organizational context on hard and soft quality management and innovation performance. International Journal of Production Economics, 185, 240-251. 